\title{
A review on bacterial stalk rot disease of maize caused by Dickeya zeae
}

\author{
Adesh Kumar ${ }^{1 *}$, Mandeep Singh Hunjan ${ }^{1}$, Harleen Kaur $^{2}$, Roomi Rawal ${ }^{3}$, Ajay Kumar \\ and P.P. Singh ${ }^{1}$
}

${ }^{1}$ Department of Plant Pathology, Punjab Agricultural University, Ludhiana (Punjab), INDIA

${ }^{2}$ Department of Plant Breeding and Genetics, Punjab Agricultural University, Ludhiana (Punjab), INDIA

${ }^{3}$ Department of Entomology, C.C.S. Haryana Agricultural University, Hisar, (Haryana) INDIA

${ }^{4}$ Department of Plant Protection, C.C.S. University Meerut (U.P.), INDIA

*Corresponding author. E-mail: adeshpp@gmail.com

Received: August 2, 2016; Revised received: February 13, 2017; Accepted: May 25, 2017

\begin{abstract}
Bacterial stalk rot of maize caused by Dickeya zeae previously known as $E$. chrysanthemi pv. zeae have economic importance of reduced crop yield up to $98.8 \%$. The disease is more prevalent in rainy season in India. The bacterium prefers high temperature and moisture for their growth result is plant toppled down within week. The pathogen has wide host range (maize, rice, tomato, chilli and brinjal etc.) which help to pathogen for long survival in soil. The bacterium characterized by biochemical and molecular tactics. In present, Pel gene and rDNA specific primers are frequently used for $D$. zeae characterization. The pathogen significantly controls under in vitro and in vivo condition via bleaching powder (drenching of $100 \mathrm{ppm}$ ) and antibiotics. The present studies generated data on pathogen nomenclature, etiology, epidemiology, host range, pathogen survival, biochemical, physiological and molecular characterization, germplasm evaluation and disease management.
\end{abstract}

Keywords: Bacterial stalk rot, Crop yield, Disease, Dickeya zeae, Maize

\section{INTRODUCTION}

Maize is the third largest planted crop after wheat and rice in the world (USDA 2014). Production of maize is constrained by a number of abiotic (unfavorable climate like high and low temperature; nutritional imbalance) and biotic factors such as mycoplasma, nematode, fungi and bacteria (Jugenheimer, 1976). Among the biotic factors the diseases caused by fungi and bacteria are economically more important because they cause heavy yield losses 8.5\% (Oerke, 2006). During the recent years bacterial stalk rot disease has emerged as one of the most important disease in kharif sown maize crop in India (Kumar et al., 2015a). The Kharif sown crop has the most susceptible stage coinciding with the annual monsoon rainfall, which aggravates the disease development. Bacterial stalk rot disease was reported for the first time by Prasad (1930), who identified the bacteria involved as $E$. dissolvens but the symptoms described by him resembled more closely to those incited by E. chrysanthemi pv. zeae. Its importance was realized during 1969 season, when a severe outbreak occurred in Mandi district in Himachal Pradesh. The pathogen spreads from plant to plant and field to field through rainwater and its runoff. The infestation of the disease was described in various parts of the world (Hingorani et al., 1959; Pauer, 1964; Prasad, 1930; Sabet, 1954; Volcani, 1961; Zachos et al., 1963; Martinez-Cisneros et al., 2014). Three bacterial pathogens have been reported to cause stalk rot of maize namely, E. dissolvens, E. chrysanthemi pv. zeae and Pseudomonas syringae pv. lapsa (Prasad 1930; Hingorani et al., 1959; Sinha, 1966). The pathogen has been recently re-classified as $D$. zeae by (Samson et al., 2005). The survey generated 458 votes from the International Community, and allowed the construction of a top 10 bacterial plant pathogen, in which Dickeya spp. found $9^{\text {th }}$ place (Mansfield et al., 2012). This bacterium has a wide host range causing soft rot (Bradbury, 1986) which make it difficult to manage this bacterium (Goto, 1979). Maize plant toppled down under severe conditions and foul odor emerges. The disease is causing causing severe grain yield losses which can range from 21 to 98 per cents (Thind and Payak 1978).

Favorable environmental conditions: Dickeya zeae is preferred high temperatures and high relative humidity for infection and disease development. High temperature and humidity important for physiological and metabolic activity of bacterium therefore its growing well and producing sufficient pectolytic enzymes which is important for plant cell degradation. It can be a problem with areas of heavy rainfall or where overhead irrigation is used and the water is pumped from a lake, pond, or slow-moving stream. Prasad and Sinha (1980) studied that a temperature of $35^{\circ} \mathrm{C}, 70 \% \mathrm{RH}$ (relative humidity) and inoculum level of $2 \times 10^{8}$ cells/ 


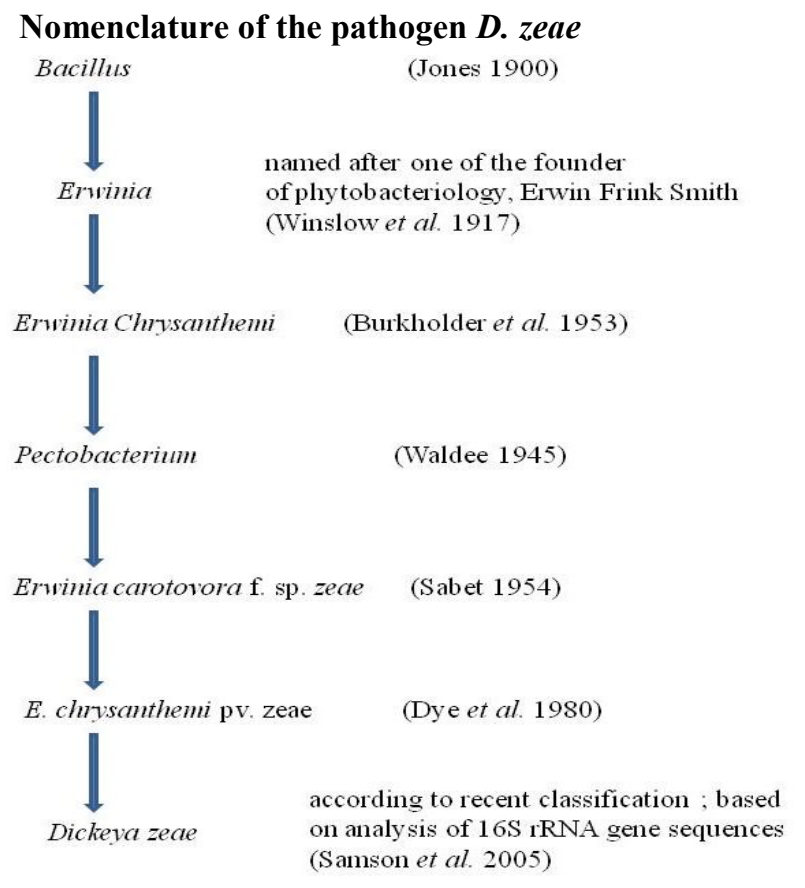

$\mathrm{ml}$ were essential for disease development in 15 to 30 day old maize plants. Saxena and Lal (1984) made an attempt to correlate weather parameter to the disease and found that temperature and RH did not fluctuate much during all the crop seasons. However, a significant difference was in total rainfall and duration of 'bright sunshine was observed. Saxena and Lal (1981) also studied positive correlation of disease with high nitrogen fertilizer.

Morphology: D. zeae is a motile, gram-negative, rod shaped bacterium. It is varying from $0.8-3.2 \times 0.5-0.8$ $\mu \mathrm{m}$ (average $1.8 \times 0.6 \mu \mathrm{m}$ ). There are $3-14$, but more usually $8-11$, peritrichous flagellae. The bacterium is produced off white, slimy and shiny colonies on King's B Medium (Fig. 1A and B) (Kumar et al. 2015b).

Pathogen mode of infection and symptoms: Initial disease symptoms include discoloration of the leaf sheath, which spread further to stalk, leaves and plant topples down in severing condition and a foul odor is detected (Fig. 2A and B). The first stage of maceration by E. chrysanthemi involves the entry of the bacteria to
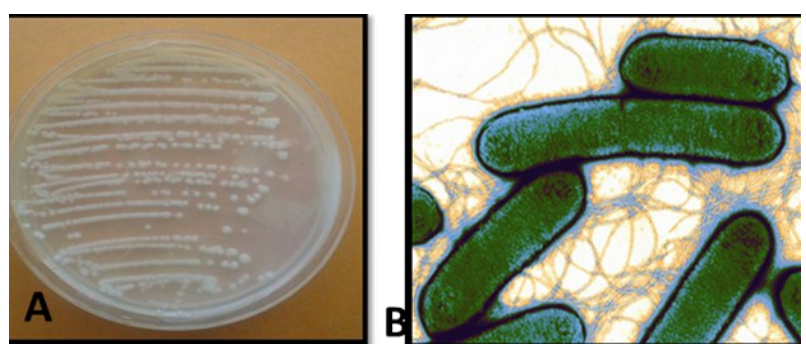

Fig. 1. A, B. Purified single colony culture of Dickeya zeae on King's B agar plate (Kumar 2015b). Electron microscopic image of Pectobacterium atrosepticum (James Hutton Institute, 2017), a species closely related to D. zeae. the parenchymatous tissues of plants that have been physiologically compromised, such as by bruising, excess water or high temperature (Collmer and Keen 1986). The next stage involves local maceration as a result of depolymerization of plant cell walls, followed by necrosis of the entire plant (Barras et al. 1994). Due to the complexity of plant cell walls, which consists of polysaccharides, the main ones being cellulose, hemicellulose and pectin, a variety of enzymes are accordingly produced by $E$. chrysanthemi for the efficient breakdown of cell walls (Robert-Baudouy et al. 2000). The major enzymes have been found to be pectinases which degrade various components of pectin using different reaction mechanisms. Other hydrolytic enzymes are also produced, such as cellulase isozymes, protease isozymes, xylanases and phospholipases (Collmer and Keen 1986; Hugouvieux-Cotte-Pattat et al., 1996; Kothari and Baig, 2013; Nahar et al., 2015). It has also been reported that $E$. chrysanthemi is capable of causing systemic disease by spreading through the vascular system of a plant. The physiological symptoms of such infection are yellowing of new leaves, wilting and a mushy, foul smelling stem rot (Slade and Tiffin, 1984). Genetic and physiological studies show that systemic infection of E. chrysanthe$m i$ is dependent on two abilities namely, iron acquisition and production of the pigment, indigoidine (Expert and Tousaint 1985; Reverchon et al., 2002). Due to iron scarcity in the environment and its role as an essential element, most organisms have derived the ability to sequester iron by production of lowmolecular-weight high affinity iron-chelating agents called siderophores. These are produced in response to iron limitation in order to capture $\mathrm{Fe} 3+$ ions. In a plant -bacteria interaction, the successful competition for iron between the two organisms could determine the outcome of an invasion (Enard et al., 1988).

Similarities to other diseases: Pythium stalk rot (Pythium aphanidermatum) causes similar symptoms on maize, but bacterial stalk rot may be accompanied by a foul odour.

Host range: $D$. zeae bacteria have a wide host range. Bradbury (1986) reported that E. chrysanthemi is causal agent of soft rot disease on wide range of plant species in tropical, subtropical and temperate region of the

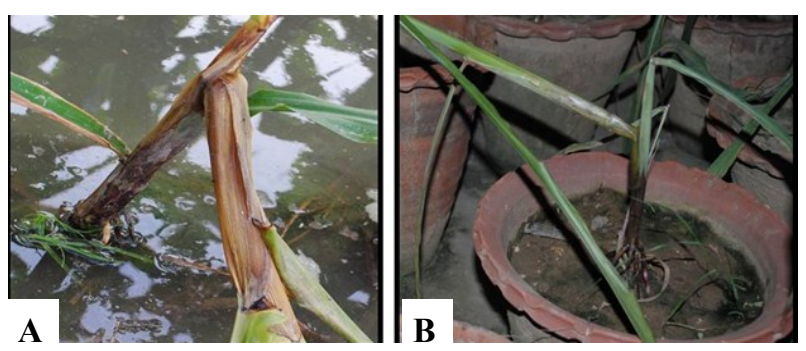

Fig. 2. A, B. Symptoms of bacterial stalk rot produced by $D$. zeae (Kumar, 2015). 
world. It attacks tubers of potato and sweet potato, onion bulbs, bean pods, roots of carrot, turnip, radish and sugar beet, fruits of tomato, brinjal, chillies and papaya and plants of pearl millet, sorghum, brinjal, potato, tomato, tobacco and cabbage (Thind, 1970; Rangarajan and Chakravarti, 1971; Hingorani et al., 1959; Mehta, 1973; Sinha and Prasad, 1977). Goto (1979) reported that E. chrysanthemi caused bacterial foot rot disease of rice in Japan. Similarly, Qiongguang and Zhenzhong (2004) reported foot rot disease of rice in China caused by E. chrysanthemi pv. zeae. Edward et al. (1973); Lakshmanan and Mohan (1980); Khan and Nagaraj (1998) reported tip-over of banana caused by E. carotovora subsp. carotovora and E. chrysanthe$m i$ from across the world. In India it was reported to be caused by E. carotovora subsp. carotovora (Edward et al. 1973; Lakshmanan and Mohan 1980; Khan and Nagaraj, 1998), while Chattopadhyay and Mukherjee (1986) attributed it to be E. chrysanthemi. Bacterial heart rot of the pineapple caused by E. chrysanthemi was first reported on Malaysia (Johnston 1957) and has since been described in Costa Rica (Chinchilla et al., 1979), Brazil, and the Philippines (Rohrbach and Johnson 2003). Erwinia chrysanthemi bacterium is also known as a greenhouse pathogen in mild climate regions (Perombelon and Kelman 1980). Stem rot caused by $E$. chrysanthemi on tomato in greenhouses has been first reported on Turkey (Cinar and Aysan, 1995). Recently, Kumar et al. (2015a) studied that D. zeae populations of Punjab have wide host range and crossinfecting many hosts (Fig. 3).

Survival: The soil represents a favorable habitat for microorganisms and is inhabited by a wide range of microorganisms, including bacteria, fungi and protozoa. D. zeae survives in plant debris but the survival period varies from different environmental conditions (Anil Kumar and Chakravarti, 1971b; Prasad and Sinha 1977; Saxena and Lal 1982). The best soil compostion for D. zeae growth is low population of PGPR (Plant growth-promoting rhizobacteria) with infected maize debris in soil. Anil Kumar and Chakravarti (1971b) studied that bacterium survived for 24, 15 and 12 weeks in infected tissue ( $40 \%$ soil moisture) at 10 , 20 and $30^{\circ} \mathrm{C}$ and for $18,15,12$ and 12 weeks (kept in soil at $27^{\circ} \mathrm{C}$ ) at $98,95,90$ and $81 \%$ relative humidity $(\mathrm{RH})$, respectively. However, population of the bacterium was reduced at $>90 \%$ moisture, due to decreases rates of organic matter decomposition, due to low oxygen supply (Csonka 1989; Killham et al.,1993). Seed survival of the bactertium which artificially inoculated also studied by Anil Kumar and Chakravarti (1971a), they found the bacterium survived for 5 months at 10 and $20{ }^{\circ} \mathrm{C}$ with 81 and $93 \% \mathrm{RH}$ and for 3-4 months at 30 and $35 \mathrm{C}$ with 51 and $62 \% \mathrm{RH}$. The bacterium survived for 140 days in autoclaved soil at $40 \%$ moisture compared to only 29 days in non-autoclaved soil (Anil Kumar and Chakravarti, 1970).

However, Rangarajan and Chakravarti (1970b) studied that stalk rot bacterium survived for 150 and 90 days in sterile and unsterile soils, respectively. Prasad and Sinha (1977) found that a sterilized environment increased the survival period of the bacterium in comparison to an unsterilized environment. It survived for 3-4 months in soil alone and for 4-6 months in soil containing healthy maize stalks. The survival period was longest (9 months) in soil which contained naturally and artificially infected maize plants as debris. Saxena and Lal (1982) also reported the longer survival period in sterilized soils and heavier soils. The maize borer, Chilo partellus, was shown to act as a carrier of this bacterium. It spreads the pathogen from diseased to healthy plants (Thind and Singh, 1976). Recently Kumar et al. (2017) studied on survival on the bacterium in vivo and in vitro condition at Punjab Agricultural University, Ludhiana. Highest survival of the pathogen (270 days) was found in both type of soils field and sterilized soil (autoclaved soil) when mixed with host (maize) debris. The period of survival was positive correlated with increase in moisture and was maximum at $90 \%$. The pathogen showed highest $\log \mathrm{cfu} / \mathrm{ml}$ at $30{ }^{\circ} \mathrm{C}$ and store

Table 1. Statistics for the 12 draft Dickeya genome sequences.

\begin{tabular}{lcccccc}
\hline Species & Strain & Accession no. & $\begin{array}{c}\text { No. of } \\
\text { Contigs }\end{array}$ & $\begin{array}{c}\text { No. of assem- } \\
\text { bled bases }\end{array}$ & N50 & $\begin{array}{c}\text { No. of predicted cod- } \\
\text { ing sequences }\end{array}$ \\
\hline D. chrysanthemi & NCPPB 402 & AOOA00000000 & 12 & $4,797,070$ & $2,467,266$ & 4,447 \\
$D$. chrysanthemi & NCPPB 516 & AOOC00000000 & 35 & $4,614,776$ & 443,362 & 4,444 \\
$D$. chrysanthemi & NCPPB 3533 & AOOJ00000000 & 91 & $4,723,912$ & 102,359 & 4,467 \\
$D$. dadantii & NCPPB $898^{\mathrm{T}}$ & AOOE00000000 & 52 & $4,933,637$ & 191,282 & 4,591 \\
$D$. dadantii & NCPPB 2976 & AOOG00000000 & 84 & $4,810,532$ & 114,781 & 4,552 \\
$D$. dadantii & NCPPB 3537 & AOOL00000000 & 47 & $4,805,222$ & 222,170 & 4,430 \\
$D$. zeae & NCPPB 2538 & AOOF00000000 & 46 & $4,559,915$ & 237,408 & 4,225 \\
D. zeae & NCPPB 3531 & AOOI00000000 & 29 & $4,623,158$ & 385,197 & 4,256 \\
D. zeae & NCPPB 3532 & AONW00000000 & 19 & $4,555,162$ & 330,312 & 4,261 \\
D. zeae & CSL RW192 & AONY00000000 & 56 & $4,696,643$ & 240,868 & 4,402 \\
D. zeae & MK19 & AOOR00000000 & 35 & $4,669,100$ & 417,168 & 4,346 \\
D. paradisiacal & NCPPB 2511 & AONV00000000 & 43 & $4,627,470$ & 160,099 & 4,376 \\
\hline
\end{tabular}



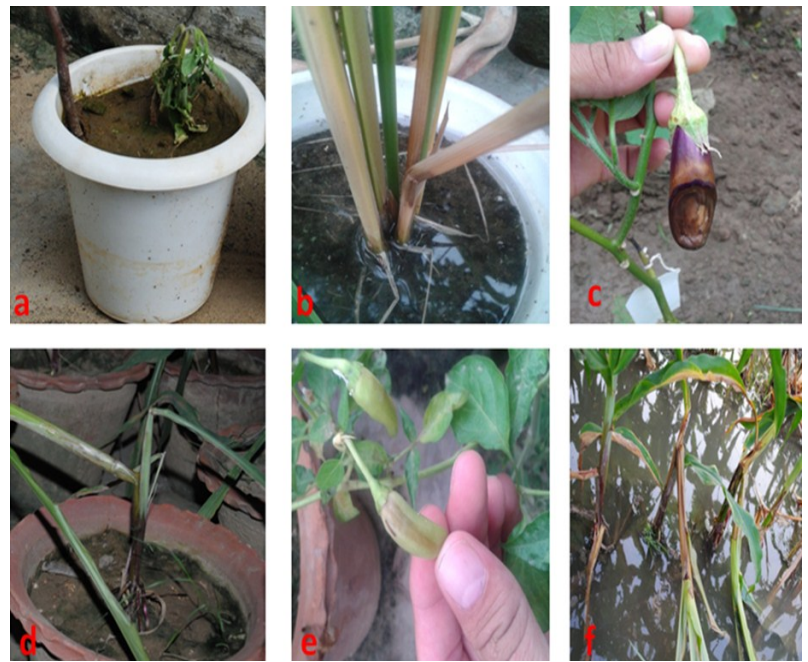

Fig. 3. Symptoms produced by D. zeae on a. tomato (Punjab Varkha bahaar-1); b. rice (Pusa 44); c. brinjal (Punjab Sadabahaar); d. maize (Punjab Sweet Corn-1); e. chilli (Punjab Lal Surkh); f. maize (Double Dekalb) (Kumar 2015).

viability of $D$. zeae was 36 months (3 years) in silica gel, while virulence of the pathogen exists only one maize crop season.

Biochemical and physiological characterization of D. zeae: Biochemical tests help to identification of different bacterial species based on the differential biochemical activities. Differences in carbohydrate, protein, fat metabolism, production of certain enzymes, ability to utilize a particular compound etc, help to be identifying the microorganisms.

Hingorani et al. (1959) studied 6 isolates collected from India and classified them as E. chrysanthemi pv. zeae, whereas Rangarajan and Chakravarti (1967) isolated bacteria from maize variety Ganga-3 and identified the bacterium as Pseudomonas lapsa. Furthermore, Dickey (1979) identified 421 strains of Erwinia species. All strain of E. chrysanthemi were separated from the others Erwinia species primarily by three physiological characters such as production of gas from D-glucose, phosphatase production and inability to produce acid from D-trehalose. The 322 strains of $E$. chrysanthemi were separated into five infrasubspecific subdivisions based on physiological properties.

Thind and Payak (1979) studied the motility and virulent characters of $E$. chrysanthemi pv. zeae with help of a medium containing 2, 3, 5-triphenyl tetrazolium bromide TTB (2, 3, 5-triphenyl tetrazolium bromide), the colony characters of cell motility and pectolytic activity can be used to differentiate virulent and avirulent cultures. Virulent types produce larger and deeper wells as compared to avirulent ones on sodium polypectate medium. Virulent cultures showed abundant motility in hanging drop and in semi-solid medium and possessed numerous flagella. While, the avirulent cells were show poor motility with few flagella, small red centres and wide colourless borders colonies on TTB.
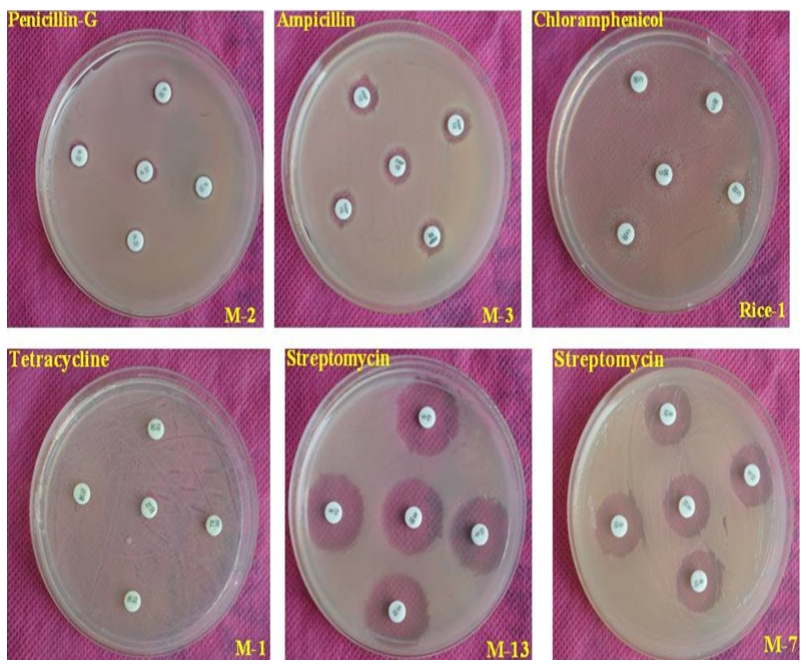

Fig.4. Sensitivity of five different antibiotics against six isolates of D. zeae using HiMedia ${ }^{\circledR}$ antibiotics discs. Except for streptomycin all the other four antibiotics were ineffective against the test isolates (Kumar 2015).

Saxena and Lal (1982) found that bacterial cells suspended in sterile water and stored at $5{ }^{\circ} \mathrm{C}$ or less remained virulent for 2 years. However, Kumar et al. (2017) observed that the virulence of the pathogen exists only one crop season but it can survive 3 years in silica gel.

Henz et al. (2006) identified 227 isolates of Erwinia spp. by biochemical and physiological tests (pectolytic activity, lecithinase, $\alpha$-methyl glucoside, phosphatase, erythromycin sensivity, growth at $37^{\circ} \mathrm{C}$ ) from arracacha roots out of which $89.9 \%$ isolates were E. chrysanthemi, $9.7 \%$ as E. carotovora subsp. carotovora and $0.5 \%$ as E. carotovora subsp. atroseptica. Furthermore, Kaneshiro et al. (2008) studied 48 strains of $E$. chrysanthemi, isolated from pine apple infected plant and irrigation water. Out of 48 isolates, 33 isolates were gram-negative, fermented glucose, formed pits on Crystal Violet Pectate (CVP) medium, reacted with $\mathrm{MAb}$ E2, and produced beige and flat colonies of dry consistencies on Yeast dextrose chalk agar (YDC) medium therefore, were presumptively identified as Erwinia species. Twenty two strains isolated from plants originally imported from Costa Rica and Honduras and 1 strain from Hawaiian irrigation water were also positive for both indigoidine and indole, suggesting that they were E. chrysanthemi. Seven of the remaining Erwinia strain were fermentative and pectolytic but negative for indigoidine and indole production, suggesting an E. carotovora identification. Nine Erwinia spp. strains isolated from banana were identified on the basis of morphological, cultural, physiological, biochemical characteristics and pathogenicity tests. Seven isolate I1 to I6 and I8 showed similarities to E. carotovora subsp. carotovora. Isolate I9 from Andhra Pradesh expressed characteristics similar to that of E. chrysanthemi and was identified as E. chry- 


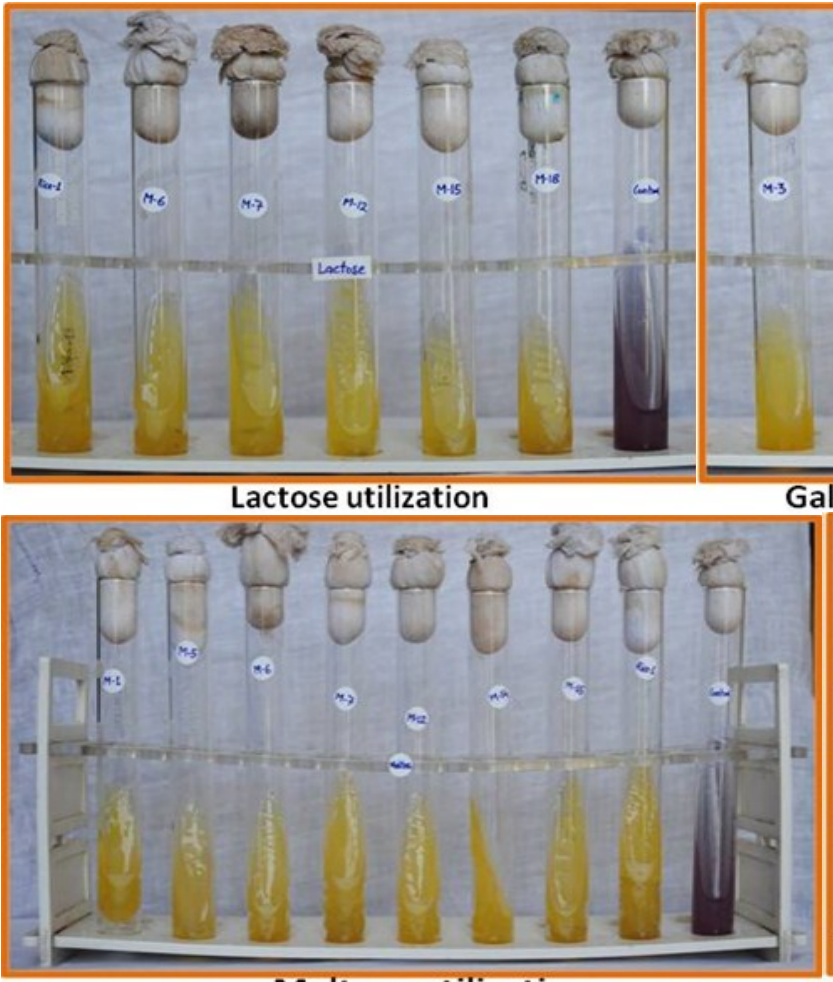

Maltose utilization

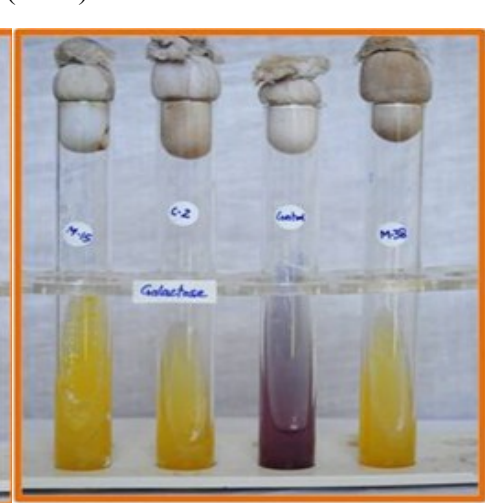

Galactose Utilization

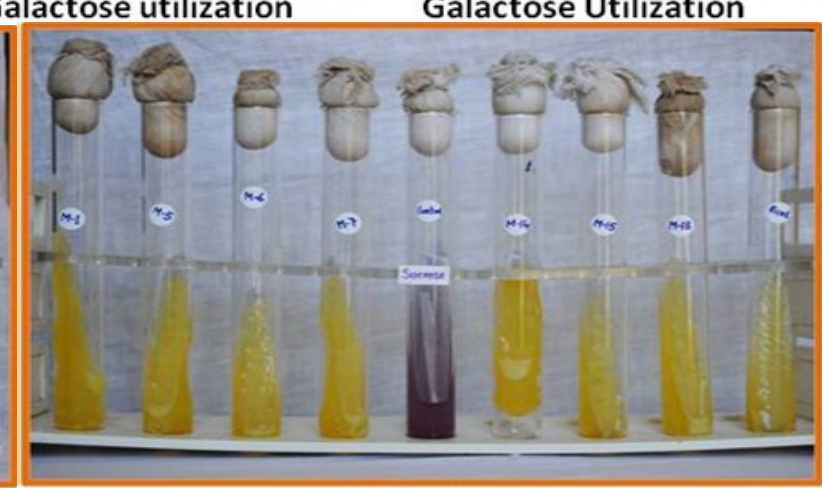

Sucrose utilization

Fig. 5. Sugar utilization by different maize isolates of D. zeae (Kumar 2015).

santhemi. The isolate I7 which showed wider variation, neither confirmed to the characteristics of $E$. $c a$ rotovora subsp. carotovora nor with that of E. chrysanthemi, nor possessed characteristics in between the two species (Snehalatharani and Khan 2010). Currentely, Kumar et al. (2015b) used 27 biochemical tests to characterize 59 isolates of $D$. zeae which showed differential reaction to utilization of carbohydrates, gelatin liquefication and growth at high salt concentration (Fig. 5). Multiple antibiotic resistances were also observed in all the isolates tested (Fig 4).

Pathotypic characterization of $D$. zeae: E. chrysanthemi is a phytopathogenic bacterium which induces soft rot and wilting Burkholder et al. (1953). The bacterium attacks a wide range of host-plants, and occurs in many areas of the world (Bradbury 1986). In phytobacteriology, infra-subspecific epithets were chosen as "pathovars" terms currently used to designate organisms on the basis of their host range (Young et al. 1978). E. chrysanthemi was first divided into 4 pathovars from the host Chrysanthemum morifolium, Dieffenbachia spp., Parthenium argentatum and Zea mays. Then 2 more pathovars were added namely pv. dianthicola from Dianthus sp and pv. paradisiaca from Musa paradisiaca. Pathovars are listed in the last Bergey's Manual of Systematic Bacteriology (Lelliott and Dickey 1984) with the mention that "the relationship between phenotypic, pathogenicity properties and serological reactions of strains of the pathovars is not entirely clear."
Cother and Powell (2008) studied nine isolates of $E$. chrysanthemi isolated from rotted potato tubers compared with 6 exist strains. Phenotypic properties of the potato isolates closely agreed with those of E. chrysanthemi pv. zeae and with the characteristics proposed for Dickey's infrasubspecific subdivision IV (1979) and Samson and Nassan-Agha's biovar 3 (1978), where Zea mays be among the most common host species. Koch's Postulate tests on twenty ornamental and agricultural species showed only Cyclamen sp. and Zeae mays to be susceptible. In ODD (Ouchterlony double diffusion) tests, antisera to whole live cells of one potato strain reacted with four of the six pathovars of E. chrysanthemi. Tuber isolates did not produce blackleg symptoms in inoculated stems. Furthermore Ali et al. (2013) studied 20 isolates of E. carotovora sub sp. atroseptica causing blackleg of the potato collected from Pakistan. Pathogenicity tests divided these 20 isolates into 4 aggressiveness groups or AGs. AG 1 (7 isolates) group was most aggressive causing an average of $5.69 \mathrm{~cm}$ rot on the potato stem.

Molecular characterization of $D$. zeae: Molecular characterization is an important tool for identification of plant pathogens with help of locus/gene specific primers. D. zeae bacterium has wide host range due to plant cell wall degrading enzymes (pectate lyase), which are important virulent factor (Barras et al., 1994; Salmond, 1994).

Darrasse et al. (1994) used pel gene sequence to identify $E$. carotovora and they were observed that tested 


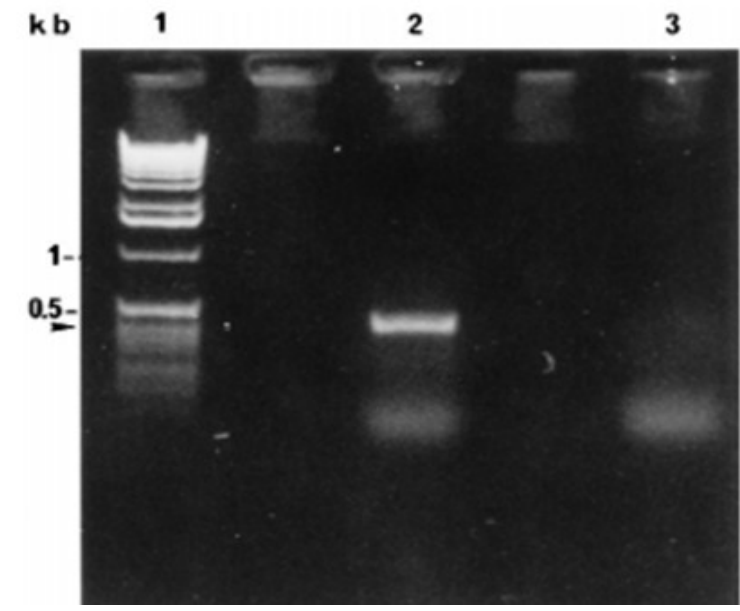

Fig. 6. $P C R$ amplification of pelADE fragments with primers $A D E 1$ and $A D E 2$. The PCR products (after 25 cycles) were separated by electrophoresis on a 1\% agarose gel. Lane 1, 1 - $k b$ DNA ladder; lane 2, E. chrysanthemi 3937. The arrowhead indicates the position of the 420-bp amplified fragment (Nassar et al., 1996)

isolates (89) present 420 bp bands. Similarly, Nassar et al. (1996) developed E. chrysanthemi specific primer set (ADE-1, ADE-2) for detection of 78 strains of $E$. chrysanthemi and they observed all starins showed 420 bps specific bands (Fig.6). Similar primers were also used by many autors for detection of that pathogen (Henz et al. 2006; Kaneshiro et al. 2008). Smid et al. (1995) developed ERWFOR and ATROREV gene specific primers and used these for characterization of E. carotovora subsp. atroseptica and E. chrysanthemi in potato. Toth et al. (2001) used AFLP fingerprinting to determine the taxonomic relationships within $E$. carotovora and E. chrysanthemi groups based on their genetic relatedness. Fessehaie et al. (2002) studied molecular characterization of DNA encoding 16S-23S rRNA intergenic spacer regions and 16S rRNA of pectolytic Erwinia species. Comparison of $16 \mathrm{~S}$ rDNA sequences from different species and subspecies clearly revealed intraspecies-subspecies homology and interspecies heterogeneity. Similarly, Slawiak et al. (2009) characterized Dickeya spp. form potato and two strains of Hyacinthus by using biochemical assays, REP-PCR genomic finger printing, 16S rDNA and DNA X sequence analysis. Furthermore, Ali et al. (2013) characterized twenty isolate of E. carotovora subspecies atroseptica (Eca) causing blackleg of potato, with help of subspecies-specific primers Eca $1 \mathrm{~F}$ and Eca $2 \mathrm{R}$.

Analysis of whole genome: Genome sequencing of the pathogens an important step to understand the mechanisms of pathogenesis and process of limit host range of the strain. The nucleotide sequence of the genomes of several phytopathogenic bacteria, such as Agrobacterium tumifaciens, Pseudomonas syringae, Ralstonia solanacearum, Xylella fastidiosa and two Xanthomonas oryzae and many species of soft rot Er- winia recently determined (Simpson et al., 2000; Buell et al., 2003; Lee et al., 2005; Salanoubat et al., 2002; Wood et al., 2001; Pritchard et al. (2013).

The Dickeya genus is recentely described six species: dianthicola, dadantii, zeae, chrysanthemi, paradisiacal and solani (Samson et al., 2005; Brady et al., 2012; Van der et al., 2013). Draft genome sequences of eight $D$. dianthicola and D. solani isolates were recently described (Pritchard et al., 2013), and four complete sequences of Dickeya strains, D. paradisiaca (Ech703), D. zeae (Ech586), D. chrysanthemi (Ech1591) and D. dadantii (Ech3937) have been deposited in GenBank (Glasner et al. (2011). Pritchard et al. (2013) announced draft genome sequences of 17 isolates of Dickeya, including 12 isolates of $D$. dadantii, D. chrysanthemi, D. zeae, and D. paradisiaca (Table 1). Similarly Bertani et al. (2013) determined sequence of $D$. zeae (DZ2Q) from diseased rice from a Roma cultivar grown in the Po Valley.

Host-plant resistance: Host plant resistance is the most economic approach to manage this disease. Identification and use of resistance sources in breeding programme have been employed by various researchers (Rangarajan and Chakravarti 1969; Thind and Payak 1976; Ebron et al. 1987; Sah and Arny 1990). Complete resistance to this pathogen has not been reported so far, but various authors have tried to identify qualitative traits loci conferring the qualitative/ multigene resistance against bacteria soft rot (Canama and Hautea 2010). Rangarajan and Chakravarti (1969) evaluated 20 maize varieties (4 composite and 16 hybrids) in the field against E. carotovora pv. zeae (M1 and M2) and observed that all varieties were resistant. Sinha and Prasad (1975) reported partial resistance against E. chrysanthemi pv. zeae in CM 600, CM 104 and CM 105 maize lines and their crosses in the field. Thind and Payak (1976) reported laboratory method (cut stalk method) for evaluation of maize lines against E. carotovora var. zeae. They observed that development of disease reaction in both laboratory and field method was similar but with some minor departures. They concluded that 'cut stalk method' can be used for screening maize germplasm.

Thind and Payak (1978) evaluated 32 maize entries consisting of 13 inbred lines, 9 hybrids, 6 composites and 4 open pollinated varieties against $E$. chrysanthe$m i \mathrm{pv}$. zeae. They observed that two inbred lines CM101, CM- 110 and two open pollinated varieties CM600, Basi were found to be tolerant against E. chrysanthemi pv. zeae. Sinha and Prasad (1981) reported that susceptibility of maize varieties was due to enhanced proteolytic enzyme activity and change in protein and total amino acid contents of stalk and leaf tissues of plant in middle and old age of crop. However, Srivastava and Prasad (1981) observed that the susceptibility of maize plants was dependent on the induction of cellulose activity by the bacterium in the infected 
tissues. Ebron et al. (1987) evaluated 107 maize accessions against bacterial stalk rot during the wet season of 1985 and 208 during the dry season of 1986 . Inoculation of test material was done by whorl inoculation techniques after 30-32 days of emergence. The percentage of bacterial stalk rot toppling were very high in both seasons of 1985 and 1986, only 8 entries out of 107 and 30 entries out of 208 maize accessions were considered resistant. Sah and Arny (1990) evaluated 45 cultivars against $E$. chrysanthemi pv. zeae and found a significant positive correlation between field and green house tests. Arun cultivar showed the lowest disease incidence $(39.2 \%)$, while the highest were recorded in PI 165982 cultivar (94.6\%). Maize hybrids and openpollinated varieties inoculated with E. chrysanthemi appeared to possess genes for resistance that can be accumulated through appropriate selection techniques (Dionio and Raymundo 1990).

Control of bacterial stalk rot disease: Bacterial stalk rot disease of maize has been managed by employing several methods such as cultural practices, biological and chemical control.

Cultural practices: The pathogen infection can be suppress via organic manure amendment which stimulates the population of beneficial microflora and avoid flooding and excessive irrigation. Ridge sowing method also helps to the farmer to manage that disease. Kumar et al. (2015c) were survey maize growing areas of Punjab and found minimum disease incidence and severity as compared to flat sown method in the farmer field.

Chemicals management: The use of many chemicals to control of E. chrysanthemi pv. zeae under in vitro and in vivo condition is widely acknowledged by several authors (Chakravarti and Rangarajan, 1966; Rangarajan and Chakravarti, 1969; Thind and Payak, 1972; Saxena and Lal, 1972, 1973, 1974; Randhawa, 1977; Randhawa and Thind, 1978; Randhawa et al. 1979; Sinha and Prasad, 1977). Sabet (1956) tried streptomycin (dihydro streptomycin sulphate) and terramycin (terramycin hydrochloride) singly and in combination on E. chrysanthemi pv. zeae under both condition (in vitro and in vivo). Both the antibiotics were effective singly and in combination against the bacterium by paper-disc methods. Sinha and Prasad (1977) screened 35 chemicals and 15 were found to be effective in disease control, when applied immediately after the inoculation of plants.

Chakravarti and Rangarajan (1966) studied effect of streptocycline on 16 species of plant pathogenic bacteria. The antibiotic was effective at all the concentrations $(25,50,100,250,500$ and $1000 \mathrm{ppm})$ against Erwinia species but E. chrysanthemi pv. zeae was highly sensitive. Rangarajan and Chakravarti (1969) made another effort and evaluated various antibiotics and fungicides against Pseudomonas lapsa and Erwinia chrysanthemi pv. zeae by paper disc method. Antibi- otics namely streptomycin, terramycin and streptocycline were found to be very effective against both the organisms at $100 \mathrm{ppm}$, while penicillin $\mathrm{G}$ was totally ineffective at all the concentration tested. Fungicides like dithane M-22, captan, flytolan, ferbam, bisdithane showed little effect against both pathogens. Many others authors also studied the effect of antibiotics on growth of E. chrysanthemi pv. zeae (Rangarajan and Chakravarti 1970a; Thind and Payak 1972; Alberghina 1974; Thind and Soni, 1983). In recently, Kumar et al. (2016) studied the copper fungicides with combination antibiotics significantly inhibit the growth of pathogen under both conditions (in vitro and in vi$v o$ ). Many authors also studied the significance role of alone antibiotics and combination with copper fungicides to control plant pathogenic bacteria in different crops (Raju et al. 2011; Ravi kumar et al., 2011; Lokesh et al., 2013).

E. chrysanthemi pv. zeae is highly sensitive to chlorine. Chlorine has property to completely inhibit the growth of the pathogen at $1 \mu \mathrm{g} / \mathrm{ml}$ under in vitro condition. Different techniques of bleaching powder were used such as sprinkling of chlorinated water between plant rows or on basal internodes of plants or broadcasting of dust or granules (coated and uncoated; containing 22 and $28 \%$ chlorine, respectively) between thé rows were effective to reducing the disease incidence significantly but the differences among them were not significant. While, application of granules between rows, first at pre-flowering and then 10 days after, was better than the other methods. Drencing of bleaching powder solution (contains $33 \%$ of chlorine) containing $100 \mu \mathrm{g} / \mathrm{ml}$ chlorine during $24 \mathrm{hs}$ before, after and at inoculation time reduced the incidence by 70, 20 and $40 \%$, respectively in potted maize plant. Thind and Payak (1972) studied that chlorinated water $(100 \mu \mathrm{g} /$ $\mathrm{ml}$ chlorine) reduced the incidence up to $75-92 \%$ when drenching applied from knee high stage to flowering stage with 15 days intervals. Similarly, Sharma et al. (1982) found that two applications of Klorocin (contains $22 \%$ chlorine) at the rate of $250 \mu \mathrm{g} / \mathrm{ml}$ chlorine resulted in significant disease control (48-28\%). It was also observed that broad cast of bleaching power in the maize field found effective which acknowledged is widely. Lal and Saxena (1978) applied bleaching powder $(25 \mathrm{~kg} / \mathrm{ha})$ at two stages, first at flowering stage and the second 10 days after, found significantly result for controlling the disease. Many authors also widely acknowledged the effect of bleaching powder to control bacterial pathogens in different crops (Padmanabhan and Jain 1966; Segall 1968; Lal et al. 1970; Dueck 1974; Verma and Upadhya 1974; Thind and Soni 1983; Shekhawat et al. 1990; Ghosh and Mandal 2009; Sharma and Kumar 2009). Recently Kumar et al. (2016) studied efficacy of five antibacterial chemicals viz., stable bleaching powder, streptocycline, cristocycline, blitox and kocide against $D$. zeae 
under in vitro and in vivo condition. Stable bleaching powder $(100 \mathrm{ppm})$ found most effective to inhibited growth of the pathogen with increased in yielding of three maize cultivars viz. Dekalb Double (52.4\%), Punjab Sweet Corn-1 (64 \%) and PMH-1(57.9\%) cultivars.

Biological control: Only few studied available on control of $D$. zeae by biological agents in case of maize as compared to other crops such as potato and tomato. Kumar et al. (2016) studied efficacy of bioagent (Pseudomonas fluorescence) against D. zeae under in vitro and in vivo condition. It was observed that $P$. fluorescence found effective only in vitro condition not in the field. Kloepper (1983) studied that application of plant growth-promoting rhizobacteria (PGPR) to potato seed, resulted in significant reduction of populations of E. carotovora in field trials. Nagaraj et al (2012) studied that tip-over disease of banana caused by Erwinia carotovora subsp. carotovora and Erwinia chrysanthemi can be controlled by antagonistic bacteria viz., Bacillus subtilis, Pseudomonas fluorescens and VAM fungi (Glomus fasciculatum).

\section{Conclusion}

The $D$. zeae prefer infection in presence of required moisture therefore bacterial stalk rot disease occurring in kharif sown maize in India. The $D$. zeae is used pectolytic enzymes as virulent factor due to this its have multi host range. The bacterium survives in soil and host debris, multi host range also help to the bacterium for long survival. The pathogen is characterized by biochemical and molecular tactics. In present, $\mathrm{Pel}$ gene and rDNA specific primers are frequently used for $D$. zeae characterization. The disease controls in the field condition with help of drenching of $100 \mathrm{ppm}$ bleaching powder and via spray of antibiotics. However, we have more need of work on resistance germplasm and other chemicals to control this disease.

\section{REFERENCES}

Alberghina, A. (1974). Inhibition of antibiotics of growth of Erwinia carotovora var. chrysanthemi. J. Phytopathol. 81: 177-83.

Ali, H.F., Junaid, M., Ahmad, M., Bibi, A., Ali, A., Hussain, S., Alam, S. and Shah, J.A. (2013). Molecular and pathogenic diversity identified among isolates of Erwinia carotovora sub-species atroseptica associated with potato blackleg and soft rot. Pak. J. Bot. 45:1073-78.

Anil Kumar, T. B. and Chakravarti, B. P. (1970). Factors affecting survival of Erwinia carotovora, causal organism of stalk rot of maize in soil. Ada Phytopathologies 35: 333-340.

Anil Kumar, T. B. and Chakravarti, B. P. (1971a). Survival of Pseudomonas lapsa and Erwinia carotovora, stalk rot pathogens of maize in seed and a medium for isolation and detection of Erwinia carotovora in soil. Proceedings of Indian National Science Academy, Section
B 37:322-325.

Anil Kumar, T. B. and Chakravarti, B. P. (1971b). Survival of maize stalk rot pathogens in infected tissue under different moisture and temperature conditions. Indian Phytopath. 24:567-570.

Barras, F., Gijsegem, F.V. and Chatterjee, A. (1994). Extracellular enzymes and pathogenesis of soft-rot Erwinia. Annu. Rev. Phytopathol. 32:201-34.

Bertani, I., da Silva D.P., Abbruscato, P., Piffanelli, P. and Venturi, V. (2013). Draft genome sequence of the plant pathogen Dickeya zeae DZ2Q, isolated from rice in Italy. Genome 6:905-13.

Bradbury, J.F. (1986). Guide to plant pathogenic bacteria. Pp. 61-101. Farnham Royal, Slough, UK: CAB International Mycological Institute.

Brady, C.L., Cleenwerck, I., Denman, S., Venter, S.N., Rodriguez-Palenzuela, P., Coutinho, T.A., De Vos, P. (2012). Proposal to reclassify Brenneria quercina (Hildebrand and Schroth 1967) Hauben et al 1999 into a new genus, Lonsdalea gen. nov., as Lonsdalea quercina comb. nov. descriptions of Lonsdalea quercina subsp. quercina comb. nov., Lonsdalea quercina subsp. iberica subsp. nov. and Lonsdalea quercina subsp. britannica subsp. nov., emendation of the description of the genus Brenneria, reclassification of Dickeya dieffenbachiae as Dickeya dadantii subsp. dieffenbachiae comb. nov., and emendation of the description of Dickeya dadantii. Int. J. Syst. Evol. Microbiol. 62:1592-1602.

Buell, C.R., Joardar, V., Lindenberg, M., Selengut, J., Paulsen, I.T., Gwnn, M.L., Dodson, R.J., Deboy, R. T. et al (2003). The complete genome sequence of the Arabidopsis and tomato pathogen Pseudomonas syringae pv. tomato DC3000. Proc. Natl. Acad. Sci. USA 100:10181-86.

Burkholder, W.H., Mc Fadden, L.H. and Dimock, A.W. (1953). A bacterial blight of chrysanthemums. Phytopathology 43:522-25.

Canama, A.O. and Hautea, D.M. (2010). Molecular mapping of resistance to bacterial stalk rot in tropical white maize. (Burk,Mcfad and Dim.). Philipp. Agric. Scientist 93:429-38.

Chakravarti, B.P. and Rangarajan, M. (1966). Streptocycline, an effective antibiotic against bacterial Plant pathogens. Hindustan Antibiot. Bull. 8:209-11.

Chattopadhyay, P.K. and Mukherjee, N. (1986). A pseudostem rot of banana due to Erwinia chrysanthemi pv. paradisiaca. Curr. Sci. 55:789-90.

Chinchilla, C.M., Gonzales, L.C. and Morales, F. (1979). Purdrición bacteriana del cogollo de la piña en Costa Rica. Agron. Costarric. 3:183-85.

Cinar, O. and Aysan, Y. (1995). Detection of Erwinia spp. causing soft rot on tomatoes grown in greenhouses in the eastern Mediterranean region. Proc $7^{\text {th }}$ Turkish Phytopathol Cong pp. 426-428, Adana, Turkey.

Collmer, A. and Keen, N.T. (1986). The role of pectic enzymes in plant pathogenesis. Annu. Rev. Phytopathol. 24:383-409.

Cother, E.J. and Powell, V. (2008). Physiological and pathological characteristics of Erwinia chrysanthemi isolates from potato tubers. J. Appl. Microbiol. 54:37-43.

Csonka, L.N. (1989). Physiological and genetic responses of bacteria to osmotic stress. Microbiol. Rev. 52:121-147. 
Darrasse, A., Priou, S., Kotoujansk, A. and Bertheau, Y. (1994). PCR and restriction fragment length polymorphism of a Pel gene as a tool to identify Erwinia carotovora in relation to potato disease. Appl. Environ. Microbiol. 60:1437-43.

Dickey, R.S. (1979). Erwinia chrysanthemi: A comparative study of phenotypic properties of strains from several hosts and other Erwinia species. Phytopathol. 69:32429.

Dionio, B.T. and Raymundo, A.D. (1990). Components of pathogenic variability and host resistance to Erwinia chrysanthemi Burk., McF. and Dim. in corn. Philippines Phytopathol. 26:42-49.

Dueck, J. (1974). Bactericidal treatment of apples for elimination of surface borne Erwinia amylovora. Can. J. Plant Sci. 54:353-58.

Ebron, L.A., Tolentino, M.S. and Lantin, M.M. (1987). Screening for bacterial stalk rot resistance in corn. Philipp. J. Crop Sci. 12:31-32.

Edward, J.C., Tripathi, S.C. and Singh, K.P. (1973). Observations on a "Tip-over" disease of banana in Allahabad. Curr. Sci. 42: 696-97.

Enard, C., Diolez, A. and Expert, D. (1988). Systemic virulence of Erwinia chrysanthemi 3937 requires a functional iron assimilation system. J. Bacteriol. 170:241926.

Expert, D. and Toussaint, A. (1985). Bacteriocin-resistant mutants of Erwinia chrysanthemi: possible involvement of iron acquisition in phytopathogenicity. J. Bacteriol. 163:221-27.

Fessehaie, A., De Boer, S.H. and Levesque, C.A. (2002). Molecular characterization of DNA encoding 16S-23S rRNA intergenic spacer regions and 16S rRNA of pectolytic Erwinia species. Can. J. Microbiol. 48: 387-98.

Ghosh, P.P. and Mandal, N.C. (2009). Some disease management practices for bacterial wilt of potato. J. Plant Protect. Sci. 1: 51-54.

Glasner, J.D., Yang C-H, Reverchon, S., Hugouvieux-CottePattat, N., Condemine, G., Bohin, J.P., Van Gijsegem, F., Yang, S., Franza, T., Expert, D., Plunkett, G., San Francisco, M. J., Charkowski, A. O., Py, B., Bell, K., Rauscher, L., Rodriguez-Palenzuela, P., Toussaint, A., Holeva, M. C., He, S. H., Douet, V., Boccara, M., Blanco, C., Toth, I., Anderson, B. D., Biehl, B. S., Mau, B., Flynn, S. M., Barras, F., Lindeberg, M., Birch, P.R.J., Tsuyumu, S., Shi, X., Hibbing, M., Yap, M.N., Carpentier, M., Dassa, E., Umehara, M., Kim, J.F., Rusch, M., Soni, P., Mayhew, G.F., Fouts, D. E., Steven, R., Gill, S.R., Blattner, F.R., Keen, N.T., Perna, N.T. (2011). Genome sequence of the plant pathogenic bacterium Dickeya dadantii 3937. J. Bacteriol. 193:2076-77.

Goto, M. (1979). Bacterial foot rot of rice caused by a strain of Erwinia chrysanthemi. Phytopathology 69:213-16.

Henz, G.P., Reifschneider, F.J.B. and Duarte, V. (2006). Erwinia chrysanthemi pectolytic bacterium causing soft rot outbreaks of arracacha in Brazil. Pesq Agropec Bras Brasília 41:1567-71.

Hingorani, M.K., Grant, U.J. and Singh, N.J. (1959). Erwinia carotovora f. sp. zeae, destructive pathogen of maize in India. Indian Phytopath. 12:151-57.

Hugouvieux-Cotte-Pattat, N., Condemine, G., Nasser, W. and Reverchon, S. (1996). Regulation of pectinolysis in Erwinia chrysanthemi. Annu. Rev. Microbiol.50:213-57.
James Hutton Institute (2017) http://www.hutton.ac.uk/ research/groups/cell-and-molecular-sciences/bacterialplant-pathogens.

Johnston, A. (1957). Bacterial heart rot of the pineapple. Malay. Agric. J. 40:2-8.

Jugenheimer, R.W. (1976). Crop Improvements, Seed Production and Uses. Pp 68. John Wiley and Sons, New York.

Kaneshiro, W.S., Burger, M., Vine, B.G., de Silva, A.S. and Alvarez, A.M. (2008). Characterization of Erwinia chrysanthemi from a bacterial heart rot of pineapple outbreak in Hawaii. Plant Dis. 92:1444-50.

Khan, A.N.A. and Nagaraj, M.S. (1998). Occurrence of a new bacterial disease on banana in Karnataka, Integrated disease management and crop loss assessment Symp. December 10-12, 1998. pp 73. Indian Phytopathological society (southern chapter), UAS, Bangalore.

Killham, K., Amato M. and Ladd J.N. (1993). Effect of substrate location in soil and soil pore-water regime on carbon turnover. Soil Biol. Biochem. 25:57-62.

Kloepper, J. W. (1983). Effect of seed piece inoculation with plant growth-promoting rhizobacteria on population of Erwinia carotovora on potato roots and daughter tubers. Phytopathology 73:217-19.

Kothari, M.N. and Baig, M.M.V. (2013). Production and characterization of extracellular polygalacturonase by erwinia carotovora MTCC 1428. Int. J. Advan. Biotech. Res. 4:118-22.

Kumar, A. (2015). Genetic diversity of Erwinia chrysanthemi $p v$. zeae causing bacterial stalk rot of maize and its management. Ph.D thesis, Department of Plant Pathology, PAU, Ludhiana.

Kumar, A., Hunjan, M.S., Kaur, H. and Singh, P.P. (2015b). Characterizing diversity of Dickeya zeae causing bacterial stalk rot of maize based on biochemical assays and antibiotic sensitivity. Indian phytopath. 68: 375-379.

Kumar, A., Hunjan, M.S., Kaur, H. Rawal R. and Singh, P.P. (2017). Studies on survival of Dickeya zeae causing agent of bacterial stalk rot disease of maize. Paper accepted in Journal : Inter. J. Agri. Sci., 9 (8): 3913-16.

Kumar, A., Hunjan, M.S., Kaur, H., Singh, P.P. and Kaur, R. (2016). Evaluation of Management of Bacterial Stalk Rot of Maize (Dickeya zeae) Using Bio-agents And Chemical Agents. J. Appl. \& Nat. Sci., 8(3): 1146-51.

Kumar, A., Hunjan, M.S., Singh, P.P. and Kaur, H. (2015a) Cross infectivity of Erwinia chrysanthemi pv. zeae isolates on different hosts. Pl. Dis. Res. 30:103-105.

Kumar, A., Hunjan, M.S., Singh, P.P. and Kaur, H. (2015c) Status of bacterial stalk rot of maize in Punjab. Pl. Dis. Res. 30:97-99.

Lakshmanan, P. and Mohan, S. (1980). Studies on rhizome rot and "Tip-over" disease of banana. Madras Agri. J. 79:56-57.

Lal, S. and Saxena, S.C. (1978). Bacterial stalk rot of maize, loss assessment and possibility of disesase control by application of calcium hypochlorite. Indian Phytopath. $31: 120$

Lal, S., Thind, B.S., Payak, M. and Ranfro, B.L. (1970). Bacterial stalk rot of maize: Resistant breeding and chemical control. Indian Phytopath. 23: 150-7.

Lee, B.M., Park, Y.J. et al (2005). The genome sequence of Xanthomonas oryzae pv. oryzae KACC10331, the bacterial blight pathogen of rice. Nucleic Acids Res. 33:577 
$-86$.

Lelliott, R.A. and Dickey, R.S. (1984). Genus VII Erwinia. Bergey's manual of systematic bacteriology. Pp. 469476. Williams and Wilkins Baltimore USA.

Lokesh, R., Erayya, Kumaranag, K.M., Chandrashekar, N., Khan, A.N.A. (2014). In vivo Efficacy of some antibiotics against bacterial blight of pomegranate caused by Xanthomonas axonopodis pv. punicae.Inter. Res. J. Biol. Sci. 3: 31-35.

Mansfield, J., Genin, S., Magori, S., Citovsky, V., Sriariyanum, M., Ronald, P., Dow, M., Verdier, V., Beer, S.V., Machado, M.A., Toth, I., Salmond, G. and Foster, G.D. (2012). Top 10 plant pathogenic bacteria in molecular plant pathology. Mol. Plant Pathol. 13:614-29.

Martinez-Cisneros, B.A., Juarez-Lopez, G., ValenciaTorres, N., Duran-Peralta, E and Mezzalama, M. (2014). First Report of Bacterial Stalk Rot of Maize Caused by Dickeya zeae in Mexico. Pl. Dis. 98:12671267.

Mehta, P. P. (1973). Investigations on bacterial stalk rot of maize in Bihar. (abstract.) p. 353. In Proceedings 60th Session Indian Science Congress Part III.

Nagaraj M S, Umashankar N, Palanna K B and Khan A N A (2012) Etiology and management of tip-over disease of banana by using biological agents. Int J Adv Biotechnol Res 2: 483-86.

Nahar, N., Haque, M.M., Khan, M.A.A. and Haque, M. A. (2015). Plant Extract Regulating Pectate Lyase Production in Soft Rotting Bacterial Isolates. The Agriculturists 13(2): 81-88.

Nassar, A., Bertheau, Y., Dervin, C., Narcy, J.P. and Lemattre, M. (1994). Ribotyping of Erwinia chrysanthemi strains in relation to their pathogenic and geographic distribution. Appl. Environ. Microbiol 60:3781-89.

Nassar, A., Darrasse, A., Lemattre, M., Kotoujansky, A., Dervin, C., Vedel, R. and Bertheau, Y. (1996). Characterization of Erwinia chrysanthemi by pectinolytic isozyme polymorphism and restriction fragment length polymorphism analysis of PCR-amplified fragments of pel genes. Appl. Environ. Microbiol. 62:2228-35.

Oerke, E. C. (2006). Crop losses to pests. J. Agri. Sci.144:31 -43 .

Padmanabhan, S.Y. and Jain, S.S. (1966). Effect of chlorination of water on control of bacterial leaf blight of rice caused by Xanthomonas oryzae (Uyeda and Ishyama). Curr. Sci. 35: 610-11.

Pauer, G.D. (1964). Erwinia carotovora f. sp. zeae, the bacterium causing stalk rot of maize in the republic of South Africa. South Africa J. Agr. Sci. 7:581-82.

Perombelon, M.C.M. and Kelman, A. (1980). Ecology of the soft rot Erwinias. Annu. Rev. Phytopathol. 18: 361-87.

Prasad, H.H. (1930). A bacterial stalk rot of maize. Indian J. Agr. Sci. 25:72.

Prasad, M. and Sinha, S. K. (1977). Survival and retention of infectivity of bacterial stalk rot pathogen of maize and its perpetuation on varied cropping pattern. Plant and Soil 47: 245-248.

Prasad, M. and Sinha, S. K. (1980). Interaction between age of maize plants, environmental factors and inoculum strength of E. carotovora var. chrysanthemi on the extent of stalk rot incidence. Zentrablatt für Bakteriologie,
Parasitenkunde, Infektionskrankheiten und Hygiene 135:55-59.

Pritchard, L., Humphris, S., Saddler, G., Parkinson, N.M., Bertrand, V., Elphinstone, J.G. and Toth, I.K. (2013). Detection of phytopathogens of the genus Dickeya using a PCR primer prediction pipeline for draft bacterial genome sequences. Plant Pathol. 62:587-96.

Qiongguang, L. and Zhenzhong, W. (2004). Infection characteristics of Erwinia chrysanthemi pv. zeae on rice. $J$. South China Agricultural University 25:55-57.

Raju, J., Benagi, V.I., Nargund, V.B., Sonavane, S. P., Mesta, R.K. (2011). In vitro evaluation of antibiotics, botanicals and bioagentsagainst bacterial blight of pomegranate caused by Xanthomonas axonopodis pv. punicae. Paper presented in National symposium on "Biology of infection, immunity and disease control in pathogenplant interactions" held at Department of Plant Sciences, School of Life Sciences, University of Hyderabad, Hyderabad, 2-4 December 2011, p. 177.

Randhawa, P. S. and Thind, B. S. (1978). Control of bacterial stalk rot of maize. (Abstract). Indian J. Mycol. Plant Pathol. 8:26.

Randhawa, P. S., Thind, B. S. and Singh, N. (1979). In vitro evaluation of chemicals against Erwinia chrysanthemi corn pathotype and Pseudomonas rubrilineans. Indian Phytopath. 32:547-550.

Randhawa, P.S. (1977). Control of bacterial stalk rots and stripe disease of Maize (Zea mays L.). M Sc thesis submitted to Punjab Agricultural University Ludhiana.

Rangarajan, M. and Chakravarti, B. P. (1970a). Studies on the control of bacterial stalk rot of maize with antibiotics. Hindustan Antibiot. Bull. 13:16-19.

Rangarajan, M. and Chakravarti, B. P. (1970b). Studies on the survival of corn stalk rot bacteria. Plant and Soil 33:140-144

Rangarajan, M. and Chakravarti, B. P. (1971). Erwinia carotovora (Jones) Holland, the inciting agent of corn stalk rot in India. Phytopathologia Mediterranea 10:4145

Rangarajan, M. and Chakravarti, B.P. (1967). A strain of Pseudomonas lapsa isolated from corn seed causing stalk rot in India. Plant Dis. Rep. 51:764-66.

Rangarajan, M. and Chakravarti, B.P. (1969). Efficacy of antibiotics and fungicides against corn stalk rot bacteria. Hindustan Antibiot. Bull. 2:177-79.

Ravi kumar, M. R., Wali, S. Y., Benagi, V.I., Patil, H. B., Patil, S. S. (2011). Management of bacterial blight of pomegranate through chemicals/antibiotics. Acta Horticulturae 890. ISHS pp. 481-482.

Reverchon, S., Rouanet, C., Expert, D. and Nasser, W. (2002). Characterization of indigoidine biosynthetic genes in Erwinia chrysanthemi and role of this blue pigment in pathogenicity. J. Bacteriol. 184: 654-65.

Robert Baudouy J., Nasser, J., Condemine, W., Reverchon, G., Shevchik, S.V.E. and Hugouvieux-Cotte-Pattat, N. (2000). Regulation of pectinase gene expression in Erwinia chrysanthemi. (eds) In Plant-Microbe Interactions. Vol 5, pp 221-268. Stacey, G., AndKeen, , N.T. St Paul, MN: APS Press,

Rohrbach, K.G. and Johnson, M.W. (2003). Pests, diseases and weeds. The Pineapple: Botany, Production and Uses. Pp.203-251.

Sabet, K.A. (1954). Etiological aspects of the bacterial root 
and stalk disease of maize. Bull. Fac. Agric. Cairo Univ. 48:17

Sabet, K.A. (1956). The effects of streptomycin and terramycin, singly and in combination, on the leaf blight disease of maize caused by Bacterium carotovorum f. sp. zeae Sabet. Ann. App. Bio. 44: 152-160.

Sah, D.N. and Arny, D.C. (1990). Susceptibility of germplasm to bacterial stalk rot caused by Erwinia chrysanthemi pv. zeae. Trop. Pest Manage. 36:154-56.

Salanoubat M, et al. (2002). Genome sequence of the plant pathogen Ralstonia solanacearum. Nature 415:497-502.

Salmond, G.P.C. (1994). Secretion of extracellular secretion factors by plant pathogenic bacteria. Annu. Rev. Phytopathol. 32:181-200.

Samson, R. and Nassan Agha, N. (1978). Biovars and Serovars Among 129 Strains of Erwinia chrysanthemi. Proc 4th Int Conf. Plant Pathogenic Bacteria. pp 54753. Angers.

Samson, R., Legendre, J.B., Christen, R., Fischer, M., Achouak, W. and Gardan, L. (2005). Transfer of Pectobacterium chrysanthemi (Burkholder et al 1953) Brenner et al 1973 and Brenneria paradisiaca to the genus Dickeya gen. nov. as Dickeya chrysanthemi comb. nov. and Dickeya paradisiaca comb. nov. and delineation of four novel species, Dickeya dadantii sp. nov., Dickeya dianthicola sp. nov., Dickeya dieffenbachiae sp. nov. and Dickeya zeae sp. nov. Int. J. Syst. Evol. Microbiol. 55:1415-27.

Saxena, A. C. and Lal, S. (1973). Corn (Zea mays) bacterial stalk rot; Erwinia carotovora var. zeae. B. \& C. Tests 29: 89 .

Saxena, S. C. and Lal, S. (1982). Studies on survival of Erwinia chrysanthemi. (abstract). Indian J. Mycol. Pl. Pathol. 12: 116.

Saxena, S. C. and Lal, S. (1984). Use of meteorological factors in prediction of Erwinia stalk rot of maize. Trop. Pest Manag. 30:82-85.

Saxena, S. C. and Lal. S. (1972). Corn (Zea mays) bacterial stalk rot; Erwinia carotovora var. zeae . B. \& C. Tests $28: 135$.

Saxena, S. C. and Lal. S. (1974). Corn (Zea mays) bacterial stalk rot; Erwinia carotovora var. zeae. B. \& C. Tests 30: 94 .

Saxena, S.C. and Lal, S. (1981). Effect of fertilizer application on the incidence of bacterial stalk rot of maize. Indian J. Mycol. Plant Pathol. 111:164.

Segall, R.H. (1968). Fungicidal effectiveness of chlorine as influenced by concentration, temperature, $\mathrm{pH}$, and spore exposure time. Phytopathology 58:1412-14.

Sharma, J.P. and Kumar, S. (2009). Linear reduction of propagules of Ralstonia solanacearum in soil by cake and chemicals. Indian Phytopath. 62: 49-53.

Sharma. S. C., Randhawa, P. S., Thind. B. S. and Khera, A. S., (1982). Use of Klorocin for the control of bacterial stalk rot and its absorption, translocation and persistence in maize tissue. Indian J. Mycol. Plant Pathol. 12: 185-190.

Shekhawat, G.S., Bhal, B. K., Kishore, V., Sangar, R.B.S., Patel, R.L., De, B.K., Sinha, S.K. and Pani, A.K. (1990). Control of bacterial wilt of potatoes by agronomic practices. J. Indian Potato Assoc. 17: 52-60.

Simpson, A.J., Reinach, F.C., Arruda, P., Abreu, F.A., Acencio, Alvarenga, R., Alves, L.M., Araya, J.E., Baia, G.S.,
Baptista, C.S., Barros, M.H. et al (2000). The genome sequence of the plant pathogen Xylella fastisiosa. $\mathrm{Na}$ ture 406:151-57.

Sinha, S.K. and Prasad, M. (1975). Varietal screening of maize germplasm against stalk rot pathogen Erwinia carotovora f. sp. zeae. Labdev J. Sci. Technol. 13:12833.

Sinha, S.K. and Prasad, M. (1977). Studies on certain aspects of chemical control of bacterial stalk rot disease of maize. Zentralblatt für Bakteriologie, Parasitenkunde, Infektionskrankheiten und Hygiene 132:81-88.

Sinha, S.K. and Prasad, M. (1981). Proteolytic enzyme activity in maize Erwinia carotovora var chrysanthemi system. Proc $3^{\text {rd }}$ International Symp 14-18 December, 1981. pp 120. Indian Phytopathological Society, New Delhi.

Slade, M.B. and Tiffin, A.I. (1984). Biochemical and serological characterization of Erwinia. In: Bergon, T. Methods in Microbiology. Vol 15, pp. 228-293. Academic Press, London.

Slawiak, S., Ven Beckhoven, J.R.C.M., Speksnijder, A.G.C.L., Czajkowski, R., Grabe, G. and Van der Wolf, J.M. (2009). Biochemical and genetical analysis reveal a new clade of biovar 3 Dickeya spp. strain isolated from potato in Europe. Eur. J. Plant Pathol. 125:24561.

Smid, E.J., Jansen, A.H.J. and Gorris, L.G.M. (1995). Detection of Erwinia carotovora subsp. atroseptica and Erwinia chrysanthemi in potato tuber using polymerase chain reaction. Plant Pathol. 44: 1058-69.

Snehalatharani, A. and Khan, A.N.A. (2010). Biochemical and physiological characterisation of Erwinia species causing tip-over disease of banana. Arch. Phytopathol. Plant Protect. 43:1072-80.

Srivastava, K.K. and Prasad, (1981). Studies on in vitro and in vivo activities of cellulose in maize - Erwinia carotovora pv. chrysanthemi host pathogen system. Proc 3rd International Symp. Proc $3^{\text {rd }}$ International Symp 14-18 December, 1981. pp 192. Indian Phytopathological Society, New Delhi.

Thind, B. S. and Payak, M. M. (1979). Differentiation of virulent and avirulent cultures of Erwinia chrysanthemi (maize pathotype). Zeitschrift für Pflanzenkrankheiten und Pflanzenschutz 86: 330-35.

Thind, B.S. (1970). Investigation of bacterial stalk rot of maize (Erwinia carotovora var. zeae Sabet). Ph.D .Thesis, Post Graduate School, Indian Agricultural Research Institute, New Delhi.

Thind, B.S. and Payak, M.M. (1972). Antibiotics and bleaching powder in the control of bacterial stalk rot of maize. Hindustan Antibiot. Bull. 15:73-74.

Thind, B.S. and Payak, M.M. (1976). A laboratory method for evaluating maize germ plasm to Erwinia carotovora var. zeae. Plant Dis. Rep. 60: 319-23.

Thind, B.S. and Payak, M.M. (1978). Evaluation of maize germplasm and estimation of losses to Erwinia stalk rot. Plant Dis. Rep. 62:319-23.

Thind, B.S. and Singh, N. (1976). Maize borer [Chilo partellus (Swinhoe)] as carrier of Erwinia carotovora var. zeae, the causal agent of bacterial stalk rot of maize. Curr. Sci. 45:117-18.

Thind, B.S. and Soni, P.S. (1983). Persistence of chlorine in maize plants and soil in relation to control of bacterial 
stalk rot of maize. Indian Phytopath. 36:687-90.

Toth, I.K., Avrova, A.O. and Hyman, L.J. (2001). Rapid identification and differentiation of the soft rot Erwinias by $16 \mathrm{~S}-23 \mathrm{~S}$ intergenic transcribed spacer-PCR and restriction fragment length polymorphism analyses. Appl. Environ. Microbiol. 67: 4070-76.

USDA (2014). http://apps.fas.usda.gov/psdonline/circulars/ production.pdf.

Van der Wolf, J.M., Nijhuis, E.H., Kowalewska, M.J., Saddler, G.S., Parkinson, N., Elphinstone, J.G., Pritchard, L., Toth, I.K., Lojkowska, E., Potrykus, M., Waleron, M., de Vos, P., Cleenwerck, I., Pirhonen, M., Garlant, L., Helias, V., Pothier, J.F., Pfluger, V., Duffy, B., Tsror, L. and Manulis, S. (2013). Dickeya solani sp. nov., a pectinolytic plant pathogenic bacterium isolated from potato (Solanum tuberosum). Int. J. Syst. Evol. Microbiol. 64:768-74.

Verma, M.L. and Upadhyay, A.R. (1974). Chemical and antibiotic control of bacterial leaf streak disease of rice (Xanthomonas translucens f. sp. oryzicola). Hindustan Antibiot. Bull. 16:197-98.

Volcani, Z. (1961). A maize stalk disease caused by a strain of Erwinia caratovora in IsraeL. J. Agr. Res. 11: 179183.

Wood, D.W., Settubal, J.C., Kaul, R., Monks, D.E., Kitajima, J.P., Okura, V.K., Zhou, Y., Chen, L., Wood, G.E. et al. (2001). The genome of the natural genetic engineer Agrobacterium tumefaciens C58. Science 294:2317-23.

Young, J.M., Dye, D.W., Bradbury, J.F., Panagopoulosc, G. and Robbs, C.F. (1978). A proposed nomenclature and classification for plant pathogenic bacteria. New Zeal. J. Agr. Res. 21:153-77.

Zachos, D.G., Panagopoulos, G.G. and Makris, S.A. (1963). A disease of maize in Greece caused by Erwinia caratovora (Jones) Holland. Ann. Inst. Phytopath Benaki. 5: 288-293. 